\section{Variation in Bloom Time in a Sour Cherry Germplasm Collection}

\author{
Amy F. Iezzoni and Colleen A. Mulinix \\ Department of Horticulture, Michigan State University, East Lansing, \\ MI 48824-1112
}

Additional index words. Prunus cerasus, phenology

\begin{abstract}
Bloom times were evaluated for seedlings from four full-sib and 14 openpollinated families of sour cherry (Prunus cerasus L.). Time of anthesis for individual seedlings ranged over 17- and 16-day periods in 1989 and 1990, respectively. In both years, most seedlings bloomed later than 'Montmorency', the only commercially important sour cherry cultivar in the United States. 'Pitic de Iasi', the parent of the latestblooming family, is a natural interspecific hybrid between sour cherry and the coldhardy Russian ground cherry ( $P$. fruticosa Pall.). Hybridization between sour and ground cherry and intense selection pressure in the colder areas of the sour cherry habitat may have favored selection of the late-blooming character.
\end{abstract}

Spring freeze damage to sour cherry flower buds is the major limiting factor to sour cherry production in the United States (Ricks, 1992). Significant crop reductions from spring freeze occur about every 3 years. Frequent reductions in production do not allow the industry to provide a consistent quantity of product to buyers, making it difficult to maintain markets.

One plant breeding approach to minimize the potential of freeze injury to sour cherry flowers is to develop late-blooming cultivars. Since flowers become increasingly sensitive to freeze injury as they develop in the spring (Ballard et al., 1971), late-blooming cultivars might have an increased chance of avoiding spring freeze damage.

The Michigan State Univ. sour cherry collection includes germplasm collected in eastem Europe, the center of diversity for sour cherry. The habitat of sour cherry in eastern Europe overlaps with that of its two progenitor species, sweet cherry ( $P$. avium L.) and the cold-hardy Russian ground cherry. Gene flow is prevalent between sour cherry and its progenitor species; as a result, sour cherry is morphologically and genetically diverse and exhibits characteristics of both progenitor species (Iezzoni et al., 1990). Phenological development under Michigan spring conditions was not known for this collection. Our objectives were to evaluate bloom time of seedlings in the sour cherry germplasm collection and identify late-blooming individuals.

Plant material. Sour cherry pollen was collected in Spring 1983 from the following locations in eastern Europe: Cacak, Yugoslavia; Plovdiv, Bulgaria; Pitesti, Romania; Budapest, Hungary; and Skierniewice, Poland. The pollen was used in Michigan in

Received for publication 24 Oct. 1991. Accepted for publication 30 June 1992. Acknowledgement is made to the Michigan Agricultural Experiment Station for their support of this research. The cost of publishing this paper was defrayed in part by the payment of page charges. Under postal regulations, this paper therefore must be hereby marked advertisement solely to indicate this fact. crosses with 'Montmorency' to generate fullsib families. Open-pollinated seeds were collected in Hungary and Romania in 1984 and 1985 , respectively. The country of presumed origin for the pollen and seed parents is presented in Hillig and Iezzoni (1988). The resulting seedlings were planted in a completely randomized design at the Clarksville Horticultural Experiment Station, Clarksville, Mich.

Data collection and analysis. In 1989 and 1990, bloom date was recorded for seedlings from four full-sib and 14 half-sib sour cherry families. Bloom date was defined as $50 \%$ open flowers and was visually estimated at 1- to 4-day intervals. Bloom date was also recorded for the cultivars Montmorency and Fruchtbare von Michurin. Heat unit accumulations for all the bloom dates recorded were calculated by the Baskerville-Emin (1969) method with a base of 10C beginning from 1 Apr., the approximate date of meiosis of cherry pollen mother cells (A.F.I., unpublished). Bloom date, defined as heat unit accumulation, was analyzed among the 18 family means, using years as replicates.

Bloom dates for the individual seedlings ranged over 17- and 16-day periods in 1989 and 1990, respectively (Table 1). 'Montmorency' bloomed on 12 May 1989 and 28 Apr. 1990. In both years, most of the seedlings bloomed later than 'Montmorency', $82 \%$ in 1989 and $59 \%$ in 1990 . 'Fruchtbare von Michurin', which had previously been shown to bloom significantly later than 'Montmorency' (Iezzoni and Hamilton, 1985), was among the latest-blooming seedlings. Because many seedlings bloom later than 'Montmorency', it should be possible to combine this character with other horticulturally important traits.

Bloom dates between years, measured by heat unit accumulation, for the sour cherry families were significantly correlated $(r=$ $\left.0.76^{* *}\right)$. Mean heat unit accumulation for full bloom among the sour cherry families differed significantly (Table 2). Differences in bloom date are not due to differences in chilling requirement. Temperatures in Michigan are sufficiently low to fulfill the chilling requirement in cherry (Anderson et al., 1986; Seif and Gruppe, 1985). Additionally, late bloom in Michigan is due to a relatively slow progression through the bloom stages and not a delay in bud burst (Iezzoni and Hamilton, 1985). Mean heat unit accumulation required for bloom of open-pollinated progeny from the family 'Pitic de Iasi' was 50 more than required by open-pollinated progeny of 'Korai Pipacs Meggy'. The family 'Montmorency' $\times \mathrm{R} 1$, which had the second lowest mean heat unit accumulation for bloom is an interspecific cross with sweet cherry $\{P$. cerasus $\times[P$. cerasus $\times(P$. cerasus $\times P$. avium)]\}, while 'Pitic de Iasi', the parent of the latest-blooming family, is a natural hybrid between sour and ground cherry.

The relationships among the sour cherry families used in our analysis of bloom date were previously studied by principal component (PC) analysis using botanical characteristics (Hillig and Iezzoni, 1988). In general, the PC analysis separated the families based on the degree of resemblance to one or the other of the progenitor species. The family, 'Montmorency' $\times$ R1, which had the second lowest mean heat unit accumulation for bloom, was located at the maximum position on $\mathrm{PC} 1$, indicating that it had numerous "sweet cherry-like" botanical traits. Located at the "ground cherry" ends of the first two PCs was a separate cluster of open-pollinated families of Russian and northern European origin: 'Pitic de Iasi', 'Lubskaya', and 'Rheinische Schattenmorelle'. In northern Europe, where winter temperatures can reach $-35 \mathrm{C}$, natural selection presumably factors those alleles contributed by the cold-hardy ground cherry; whereas in the milder climates of southern and western Europe, alleles contributed by sweet cherry may have an adaptive advantage.

Table 1. Number and percentage of sour cherry seedlings blooming over 17- and 16-day periods in 1989 and 1990 , respectively.

\begin{tabular}{|c|c|c|c|c|}
\hline \multirow[b]{2}{*}{ Date } & & \multirow{2}{*}{$\begin{array}{l}\text { Heat unit } \\
\text { accumulation } \\
\text { from } 1 \text { Apr. }\end{array}$} & \multicolumn{2}{|c|}{ Seedlings } \\
\hline & & & No. & $\%$ \\
\hline \multirow{9}{*}{ May } & & 1989 & & \\
\hline & 8 & $125^{z}$ & 3 & 1.0 \\
\hline & 10 & 138 & 21 & 7.0 \\
\hline & $12^{y}$ & 149 & 31 & 10.3 \\
\hline & 15 & 172 & 77 & 25.7 \\
\hline & 17 & 204 & 114 & 38.0 \\
\hline & 19 & 240 & 44 & 14.7 \\
\hline & $22^{x}$ & 283 & 8 & 2.7 \\
\hline & 24 & 327 & 2 & 0.7 \\
\hline \multirow{4}{*}{ April } & & 1990 & & \\
\hline & 26 & 91 & 3 & 1.0 \\
\hline & 27 & 111 & 43 & 14.3 \\
\hline & $28^{y}$ & 126 & 78 & 26.0 \\
\hline \multirow{5}{*}{ May } & 29 & 137 & 18 & 6.0 \\
\hline & 30 & 144 & 70 & 23.3 \\
\hline & 3 & 153 & 40 & 13.3 \\
\hline & 7 & 170 & 27 & 9.0 \\
\hline & $10^{x}$ & 197 & 21 & 7.0 \\
\hline
\end{tabular}

${ }^{2}$ Heat unit accumulation calculated by Baskerville-Emin (1969) method with a base of 10C. 'Bloom date for 'Montmorency'.

'Bloom date for 'Fruchtbare von Michurin.' 
Table 2. Mean number of heat units accumulated for full bloom for progeny from 18 sour cherry families in Spring 1989 and 1990.

\begin{tabular}{|c|c|}
\hline Family & $\begin{array}{l}\text { Mean heat } \\
\text { unit } \\
\text { accumu- } \\
\text { lation }\end{array}$ \\
\hline Korai Pipacs Meggy (op) ${ }^{y}$ & $147^{x}$ \\
\hline Montmorency $\times \mathrm{R} 1$ & 153 \\
\hline Dobraia (op) & 153 \\
\hline Erdi Jubileum (op) & 154 \\
\hline Pandy (op) & 154 \\
\hline Wolynska (op) & 156 \\
\hline Starks' Montmorency (op) & 161 \\
\hline Nefris (op) & 162 \\
\hline Montmorency $\times$ Nefris & 163 \\
\hline Cigany Meggy (op) & 165 \\
\hline D076 (op) & 165 \\
\hline Montmorency $\times$ Meteor Korai & 165 \\
\hline Montmorency x M63 & 166 \\
\hline Montmorency (op) & 171 \\
\hline Kantorjanosi (op) & 175 \\
\hline Lubskaja (op) & 180 \\
\hline Rheinische Schattenmorelle (op) & 188 \\
\hline Pitic de Iasi (op) & 199 \\
\hline LSD $(0.05)$ & 11 \\
\hline
\end{tabular}

${ }^{7}$ Heat unit accumulation calculated by Baskervilla-Emin (1969) method with a base of 10C.

(op) $=$ Open-pollinated seedlings.

Open-pollinated progeny from 'Pitic de Iasi', 'Lubskaya', and 'Rheinische Schattenmorelle', were the latest-blooming, suggesting that this character is most prevalent in germplasm from more northern areas. This conclusion agrees with previous reports of late-blooming sour cherry cultivars, all of which originated in the former Soviet Union (Iezzoni and Hamilton, 1985; Simoviki, 1959-60). The late-blooming character that may have been contributed by ground cherry is presumably an important trait in the northern environment.

\section{Literature Cited}

Anderson, J.L., E.A. Richardson, and C.D. Kesner. 1986. Validation of chill unit and flower bud phenology models for 'Montmorency' sour cherry. Acta Hort. 184:71-78.

Ballard, J.K., E.L. Proebsting, and R.B. Tukey. 1971. Critical temperatures for blossom buds: Cherries. Wash. State Univ. Coop. Ext. Circ. no. 371.

Baskerville, G.L. and P. Emin. 1969. Rapid estimation of heat unit accumulation from maximum and minimum temperatures. Ecology 50:514-517.

Hillig, K.W. and A.F. Iezzoni. 1988. Multivariate analysis of a sour cherry germplasm collection. J. Amer. Soc. Hort. Sci. 113:928-934.

Iezzoni, A., H. Schmidt, and A. Albertini. 1990. Cherries (Pnmus spp.), p. 110-173. In: J.N. Moore and J. Ballington (eds.). Genetic resources of temperate fruit and nut crops. Acta Hort., Wageningen, Netherlands.

lezzoni, A.F. and R.L. Hamilton. 1985. Differences in spring floral bud development among sour cherry cultivars. HortScience 20:915-916.

Ricks, D. 1992. Supply fluctuations and long-term acreage cycles in tart cherries and other tree crop industries. Great Lakes Fruit Growers News 31(2):22, 24.

Seif, S. and W. Gruppe. 1985. Chilling require- ments of sweet cherries (Prunus avium) and interspecific cherry hybrids (Prunus $\times$ ssp.). Acta Hort. 1969:289-294.

Simoviki, K. 1959-60. Relation between flower- ing time of fruit trees and frost period in the Macedonian People's Republic (in Russian, English summary). Godisen Zb. Zemjodsum. Fak. Univ. Skopje. 13:5-57. 